\title{
PEMBERDAYAAN MASYARAKAT DENGAN PENGEMBANGAN POTENSI SUMBERDAYA ALAM DI DESA PAKOWA BUNTA KECAMATAN NUHON KABUPATEN BANGGAI
}

\author{
Oleh : \\ Sri Sukari Agustina ${ }^{(1)}$, dan Ratmi Rosilawati ${ }^{(2)}$ \\ ${ }^{(1)}$ Staf Pengajar Fakultas Perikanan Universitas Muhammadiyah Luwuk \\ asrisukari@yahoo.com \\ ${ }^{(2)}$ Staf Pengajar Fakultas Pertanian Universitas Muhammadiyah Luwuk \\ amy.nazir@yahoo.co.id
}

\begin{abstract}
Abstrak
Tujuan utama pelaksanaan KKN-PPM ini adalah meningkatkan partisipasi masyarakat Desa Pakowa Bunta dalam mengelola potensi sumberdaya alam yang tersedia di wilayahnya dan menjadikan Desa Pakowa Bunta sebagai daerah yang memiliki kapasitas dalam pengelolaan produktivitas usaha untuk menciptakan pemberdayaan masyarakat yang berbasiskan pembelajaran pembangunan berkelanjutan. Metode pelaksanaan yang dilakukan untuk mewujudkan luaran KKN PPM yaitu peningkatan produksi, efisiensi, peningkatan partisipasi, perbaikan system dan peningkatan swadana dan swadaya masyarakat dengan metode partispatif, dimana seluruh kegiatan KKN-PPM dilaksanakan bersama oleh masyarakat dan peserta KKNPPM. Perguruan Tinggi dalam hal ini mahasiswa KKN-PPM beserta dosen pendamping lapangan dan narasumber sebagai motivator dan fasilitator terhadap pelaksanaan kegiatan, memberikan introduksi ilmu pengetahuan dan teknologi (IPTEK) terhadap kegiatan yang memerlukan teknologi. Berdasarkan hasil kegiatan KKN-PPM diperoleh output kegiatan yaitu meningkatnya pengetahuan dan keterampilan masyarakat dalam : (1) mengolah dan membuat kelapa menjadi minyak goreng Bio Virgin, (2) memanfaatkan limbah pertanian menjadi pupuk organik padat, (3) manajemen dan mengelola kelompok simpan pinjam untuk usaha perempuan (SPP), (4) sosialisasi budidaya ikan dan membuat pakan ikan dan (5) membuat kerajinan dari tempurung kelapa yang mempunyai nilai ekonomi lebih tinggi.
\end{abstract}

Kata kunci : sumberdaya alam, potensi, KKN-PPM

\section{PENDAHULUAN}

Kecamatan Nuhon Kabupaten

Banggai merupakan kecamatan yang terbentuk dari hasil Pemekaran Kecamatan Bunta Kabupaten Kanggai. Kecamatan Nuhon terdiri dari 17 desa, diantaranya Desa Pakowa Bunta. Desa Pakowa Bunta berjarak $100 \mathrm{M}$ dari pusat pemerintahan kecamatan, berjarak $143 \mathrm{Km}$ dari Kota Luwuk ibu kota Kabupaten Banggai, dan berjarak $700 \mathrm{Km}$ dari Kota Palu ibu kota Provinsi Sulawesi Tengah. Desa Pakowa Bunta memiliki lingkunan pemukiman sebanyak dua dusun dengan luas wilayah $\pm 14,92 \mathrm{Km}^{2}$. Desa Pakowa Bunta secara fisik merupakan dataran rendah yang berada di garis pantai memiliki batas wilayah administratif sebelah utara Desa Petak, sebelah selatan Desa Tomeang/Desa Pibombo, sebelah barat Teluk Tomini dan sebelah timur Desa Bolobungkang.

Jumlah penduduk Desa Pakowa Bunta saat ini berjumlah 494 jiwa, terdiri dari 288 laki-laki dan 229 perempuan, Jumlah Rumah Tangga 132 KK yang terdiri dari Rumah Tangga miskin berjumlah $92 \mathrm{KK}$, Rumah Tangga pra sejahtera $21 \mathrm{KK}$ dan Rumah Tangga sejahtera $21 \mathrm{KK}$. Penduduk desa ini didominasi oleh penduduk yang bermata pencaharian petani, baik sebagai petani tanaman pangan atau sawah, petani tegalan, petani kebun, dan pembudidaya ikan sebahagian penduduk juga mempunyai ternak. 
Pekerjaan lain yang dijalani oleh petani dengan teknologi yang sangat sederhana adalah membuat pengolahan keripik pisang, abon ikan, dan pengolahan kopra. Masyarakat Desa Pakowa Bunta, tergabung dalam beberapa kelompok tani yaitu 12 kelompok Simpan Pinjam Usaha Perempuan (SPP), 3 kelompok gabungan kelompok tani (Gapoktan), 3 kelompok budidaya ikan (1 kelompok Pohumpaki dan 2 kelompok Anugrah Jaya), 1 kelompok ternak sapi (Harapan), dan 1 kelompok ternak kamping Etawa (Mandiri). Potensi desa yang belum terkelola dengan baik di desa ini adalah potensi perkebunan, potensi lahan kolam ikan, potensi limbah pertanian, potensi kelompok simpan pinjam untuk usaha perempuan (SPP) serta potensi sumberdaya alam lainnya seperti pohon kelapa yang seluruhnya dapat dimanfaatkan untuk memproduksi produkproduk yang bernilai ekonomi untuk mensejahterakan warga desa.

Permasalahan utama yang dihadapi oleh masyarakat Desa Pakowa Bunta adalah :

1. Luasnya areal perkebunan kelapa dan potensi produksi kelapa sangat tinggi sementara pengetahuan dan keterampilan masyarakat dalam pengolahan kelapa masih rendah

2. Luasnya areal budidaya ikan sementara pengetahuan dan keterampilan masyarakat dalam budidaya ikan juga produktivitas ikan di desa lokasi KKN-PPM masih rendah

3. Limbah ternak dan limbah pertanian belum dimanfaatkan karena pengetahuan dan keterampilan masyarakat dalam memanfaatkan limbah pertanian menjadi bernilai ekonomi masih rendah

4. Banyaknya kelompok simpan pinjam perempuan sementara pengetahuan dan keterampilan masyarakat dalam manajemen dan mengelola kelompok simpan pinjam untuk usaha perempuan (SPP) masih rendah

5. Terbatasnya pengetahuan dan keterampilan masyarakat dalam pembuatan kerajinan dari tempurung kelapa yang mempunyai nilai ekonomi lebih tinggi.

Masalah-masalah yang dialami masyarakat Desa Pakowa Bunta Kecamatan Nuhon di atas membuka peluang bagi mahasiswa KKN-PPM beserta Tim Dosen
Pendamping Lapangan (DPL) dari Universitas Muhammadiyah Luwuk untuk hadir memberikan solusi demi menyelesaikan permasalahan yang terjadi. Hal ini sejalan dengan pilar utama Universitas Muhammadiyah Luwuk yang tertata dalam Tri Dharma Perguruan Tinggi, khususnya pilar pengabdian masyarakat. Tujuan KKNPPM Universitas Muhammadiyah Luwuk di Desa Pakowa Bunta Kecamatan Nuhon Kabupaten Banggai adalah untuk meningkatkan partisipasi masyarakat Desa Pakowa Bunta dalam mengelola potensi sumberdaya alam yang tersedia di wilayahnya dan menjadikan Desa Pakowa Bunta sebagai daerah yang memiliki kapasitas dalam pengelolaan produktivitas usaha untuk menciptakan pemberdayaan masyarakat yang berbasiskan pembelajaran pembangunan berkelanjutan.

\section{METODE PELAKSANAAN}

Metode pelaksanaan yang dilakukan untuk mewujudkan luaran KKN PPM yaitu peningkatan produksi, efisiensi, peningkatan partisipasi, perbaikan system dan peningkatan swadana dan swadaya masyarakat dengan metode partispatif, dimana seluruh kegiatan KKN-PPM dilaksanakan bersama oleh masyarakat dan peserta KKN-PPM. Perguruan Tinggi dalam hal ini mahasiswa KKN-PPM beserta dosen pendamping lapangan dan narasumber sebagai motivator dan fasilitator terhadap pelaksanaan kegiatan, memberikan introduksi ilmu pengetahuan dan teknologi (IPTEK) terhadap kegiatan yang memerlukan teknologi. Langkah-langkah pelaksanaan metode tersebut meliputi :

\section{Persiapan dan Pembekalan}

Pada tahap ini kegiatan yang dilaksanakan diawali dengan sosialisasi kepada mahasiswa calon peserta KKN-PPM di Universitas Muhammadiyah Luwuk. Kegiatan ini dilaksanakan untuk memberikan pemahaman kepada seluruh mahasiswa tentang tujuan KKN-PPM serta penyampaian keadaan umum lokasi KKNPPM kepada mahasiswa. Selanjutnya dilakukan rekruitmen mahasiswa dan pelaksanaan pembekalan.

\section{Pelaksanaan Kegiatan}


Pada tahap pelaksanaan kegiatan dimulai dengan sosialisasi kepada masyarakat sasaran di desa lokasi KKN-PPM, dilanjutkan dengan pelaksanaan kegiatankegiatan pelatihan yang meliputi pelatihan teknis (pelatihan pengolahan kelapa menjadi minyak goreng Bio Virgin, pelatihan pembuatan pupuk organik padat dari limbah pertanian dan pelatihan budidaya ikan dan pembuatan pakan ikan), pelatihan manajemen (pelatihan manajemen kelompok simpan pinjam untuk usaha perempuan) dan pelatihan keterampilan (pelatihan pembuatan kerajinan dari tempurung kelapa).

\section{HASIL DAN LUARAN YANG DICAPAI}

Pelaksanaan kegiatan Kuliah Kerja

Nyata Pembelajaran Pemberdayaan

Masyarakat (KKN-PPM) Universitas

Muhammadiyah Luwuk Tahun 2016

"Pemberdayaan Masyarakat Dengan

Pengembangan Potensi Sumberdaya Alam di Desa Pakowa Bunta Kecamatan Nuhon Kabupaten Banggai" seluruh mekanisme mulai dari rekruitmen, proses pendaftaran, penempatan, dan pelaksanaan program di lapangan sampai pada tanggal 30 Oktober 2016 telah dilaksanakan 100\%. Program KKN-PPM diarahkan pada pemberdayaan masyarakat dalam mengembangkan potensi sumberdaya alam di Desa Pakowa Bunta Kecamatan Nuhon Kabupaten Banggai.

Hasil pelaksanaan program kerja yang telah dilaksanakan dalam program hibah KKN-PPM Universitas Muhammadiyah Luwuk di Desa Pakowa Bunta Kecamatan Nuhon Kabupaten Banggai tahun 2016 dijabarkan sebagai berikut :

\section{Sosialisasi dan Pembekalan}

Sosialisasi pelaksanaan kegiatan KKNPPM Universitas Muhammadiyah Luwuk tahun 2016 dilaksanakan baik terhadap mahasiswa calon peserta KKN-PPM maupun masyarakat pengguna dalam hal ini masyarakat Desa Pakowa Bunta Kecamatan Nuhon Kabupaten Banggai. Sosialisasi pelaksanaan KKN-PPM Universitas Muhammadiyah Luwuk pada mahasiswa calon peserta KKN-PPM dilaksanakan pada tanggal 12 Agustus 2016, sedangkan sosialisasi pelaksanaan KKN-PPM terhadap masyarakat Desa
Pakowa Bunta Kecamatan Nuhon dilaksanakan pada tanggal 13 Agustus 2016. Sebelum mahasiswa diterjunkan ke desa, diberikan pembekalan selama 1 hari (08.00-21.00 WITA) pada tanggal 14 September 2016 di ruang Aula Universitas Muhammadiyah Luwuk dengan substansi materi (1) Keadaan umum lokasi KKN-PPM, (2) Metode pemberdayaan masyarakat, (3) Teknologi Tepat Guna meliputi teknologi pengolahan kelapa, pembuatan minyak bio virgin, pembuatan pupuk organik padat, dan pembuatan pakan ikan, (4) Manajemen dan pengelolaan usaha simpan pinjam, (5) Pengenalan berbagai kerajinan dari tempurung kelapa, dan (6) Administrasi KKN-PPM.

2. Penyerahan Mahasiswa KKN-PPM dan Sosialisasi Kegiatan Kerja KKN-PPM

Prosesi penyerahan mahasiswa secara formal dilakukan di kantor desa Pakowa Bunta yang disaksikan pembimbing, aparat desa dan pemuka adat masyarakat pada tanggal 15 September 2016. Selama pelaksanaan KKN, mahasiswa wajib tinggal di desa selama 24 jam dengan mengambil tempat tinggal yang sudah disediakan oleh masyarakat desa. Untuk melaksanakan kegiatan kerja KKN-PPM yang terjadwal dan tertuang dalam papan program kerja, maka dilaksanakan sosialisasi kegiatan kerja KKN-PPM terhadap masyarakat Desa Pakowa Bunta Kecamatan Nuhon di kantor desa pada tanggal 16 September 2016.

\section{Pelaksanaan Kegiatan}

\subsection{Pelatihan Pengolahan Kelapa Terpadu dan Pembuatan Minyak Bio Virgin}

Pelatihan pengolahan kelapa terpadu dan pembuatan minyak bio virgin pada masyarakat di Desa Pakowa Bunta Kecamatan Nuhon Kabupaten Banggai dilaksanakan pada tanggal 19-25 September 2016 dan tanggal 23-26 Oktober 2016 di Balai Desa dan Gudang Koperasi Desa Pakowa Bunta Kecamatan Nuhon. Pelatihan ini bertujuan untuk meningkatnya pengetahuan dan keterampilan masyarakat di lokasi KKN-PPM dalam mengolah dan membuat kelapa menjadi minyak goreng Bio Virgin.

Kegiatan pelatihan pengolahan kelapa terpadu dan pembuatan minyak bio virgin 
terdiri dari pemaparan materi kegiatan dan kegiatan teknis di lapangan. Peserta kegiatan adalah masyarakat Desa Pakowa Bunta Kecamatan Nuhon. Dalam pelaksanaan kegiatan ini berhasil $100 \%$ dan tidak ditemukan kendala yang berarti. Ketersediaan peralatan dan bahan untuk pembuatan pembuatan minyak bio virgin yang berasal dari potensi lokal desa sangat mendukung dalam kegiatan ini. Respon dari masyarakat Desa Pakowa Bunta Kecamatan Nuhon dalam mengikuti pelaksanaan kegiatan ini sangat mendukung. Kegiatan ini diharapkan agar masyarakat Desa Pakowa Bunta Kecamatan Nuhon dapat memanfaatkan secara optimal potensi perkebunan kelapa yang tersedia di desa sehingga masyarakat memiliki daftar program peningkatan produksi minyak Bio Virgin. Dokumentasi kegiatan pelatihan pengolahan kelapa terpadu, proses pembuatan dan produk minyak bio virgin tertuang pada Gambar 1.
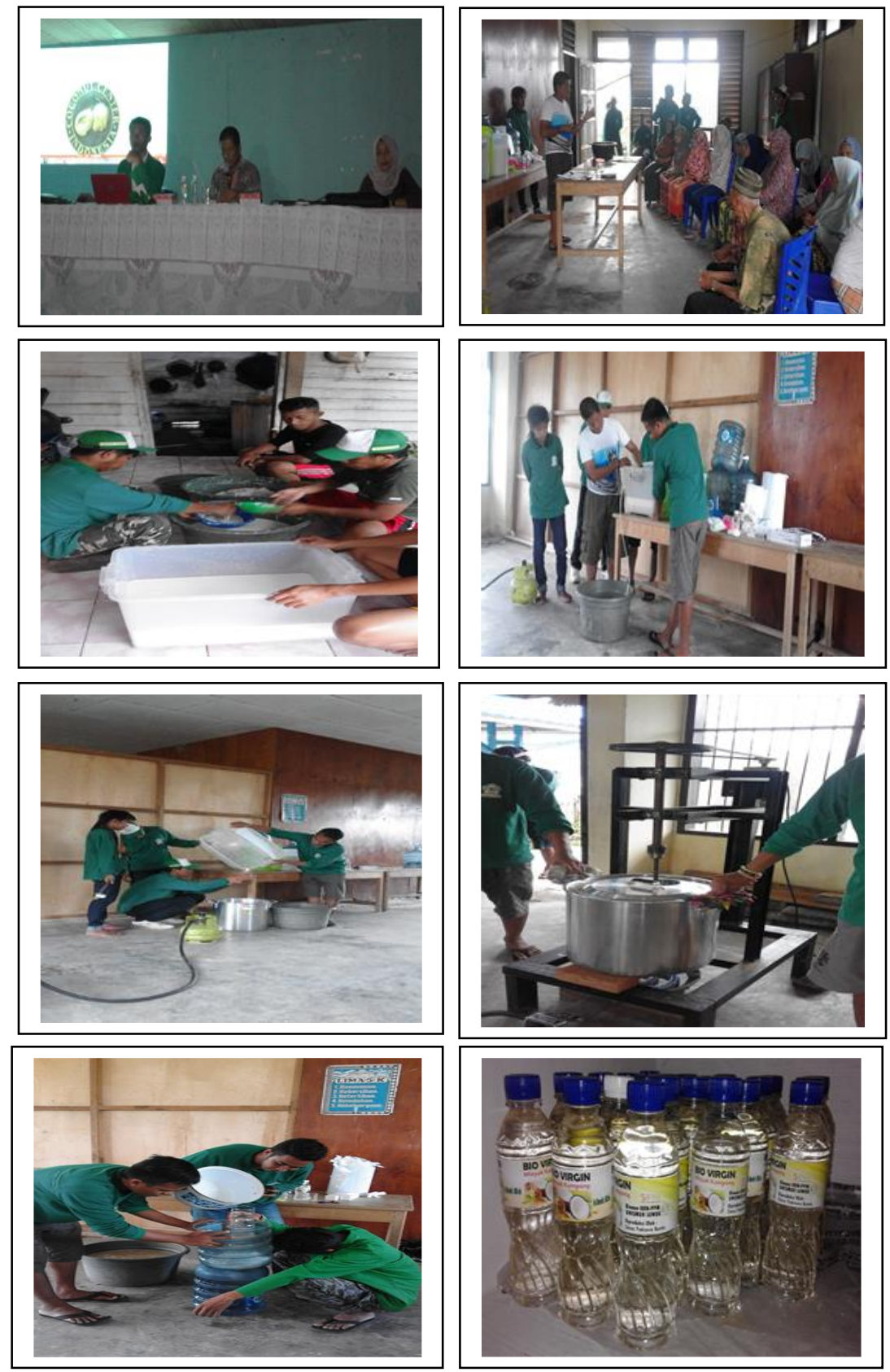

Gambar 1. Pelatihan pengolahan kelapa, proses pembuatan dan produk minyak bio virgin 


\subsection{Pelatihan dan Pembuatan Pupuk Organik Padat}

Pelatihan dan pembuatan pupuk organik padat pada masyarakat petani di Desa Pakowa Bunta Kecamatan Nuhon Kabupaten Banggai dilaksanakan pada tanggal 26-27 September 2016 di Gudang Koperasi Desa Pakowa Bunta Kecamatan Nuhon. Sedangkan proses pembalikan pupuk organik padat sampai pengemasan dilakukan pada tanggal dan tanggal 28 September 2016 - 10 Oktober 2016. Pelatihan dan pembuatan pupuk organik padat ini bertujuan untuk meningkatnya pengetahuan dan keterampilan masyarakat di lokasi KKN-PPM dalam memanfaatkan limbah pertanian menjadi bernilai ekonomi.

Kegiatan pelatihan dan pembuatan pupuk organik padat terdiri dari pemaparan materi kegiatan dan praktek teknis di lapangan. Peserta kegiatan adalah masyarakat petani Desa Pakowa Bunta Kecamatan
Nuhon. Dalam pelaksanaan kegiatan ini berhasil $100 \%$ dan tidak ditemukan kendala yang berarti. Ketersediaan peralatan dan bahan untuk pembuatan pupuk organik padat yang berasal dari desa sangat mendukung dalam kegiatan ini. Respon dari masyarakat Desa Pakowa Bunta Kecamatan Nuhon dalam mengikuti pelaksanaan kegiatan ini sangat mendukung. Kegiatan ini diharapkan agar masyarakat Desa Pakowa Bunta Kecamatan Nuhon dapat memanfaatkan secara optimal materi dan praktek secara teknis pembuatan pupuk organik padat sehingga sehingga masyarakat petani Desa Pakowa Bunta Kecamatan Nuhon mempunyai sentra produksi pupuk organik padat serta adanya kelompok usaha pupuk organik padat. Dokumentasi kegiatan pelatihan, proses pembuatan dan produk pupuk organik padat tertuang pada Gambar 3 dan Gambar 4.
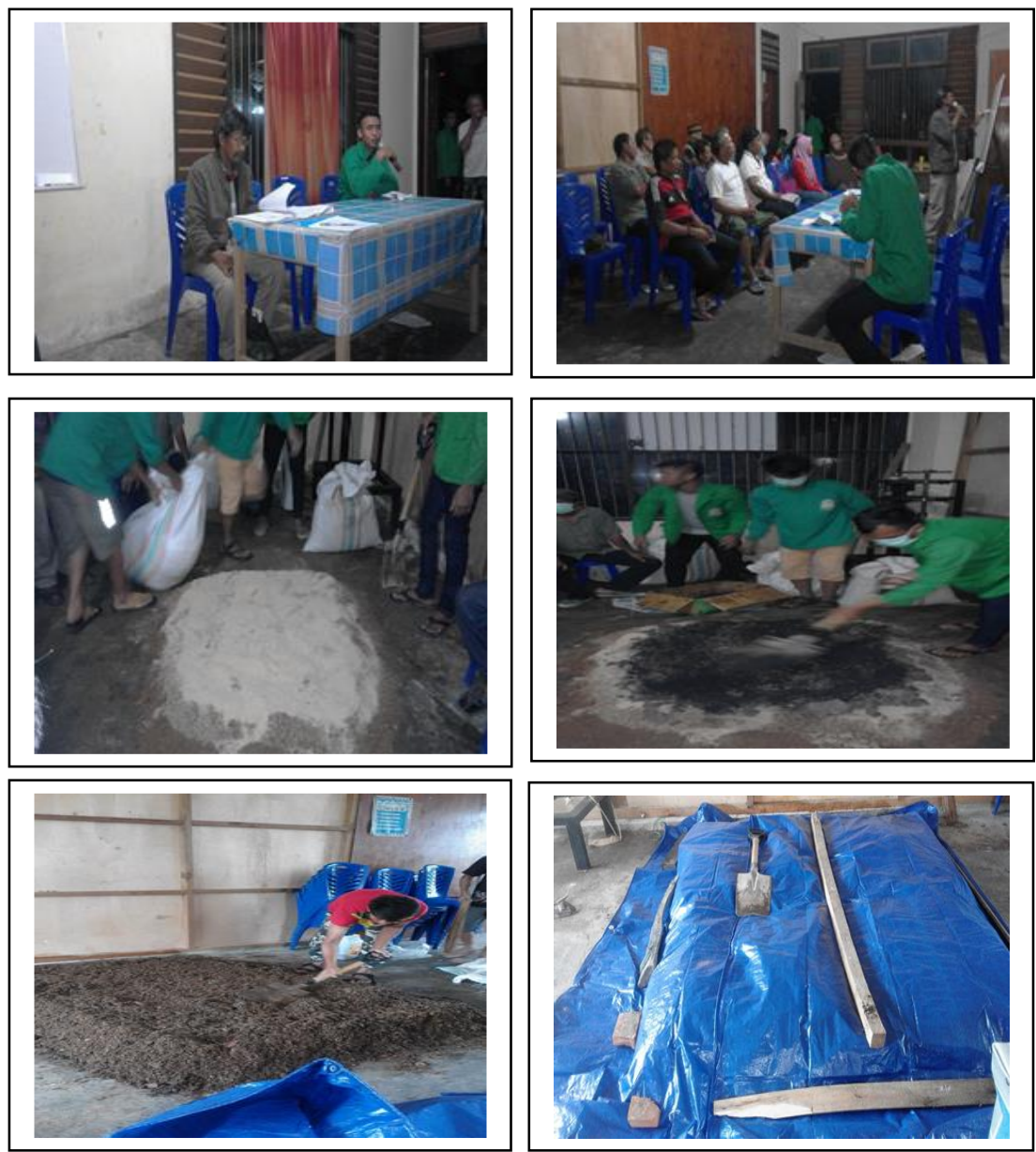

Gambar 3. Pelatihan dan proses pembuatan pupuk organik padat 

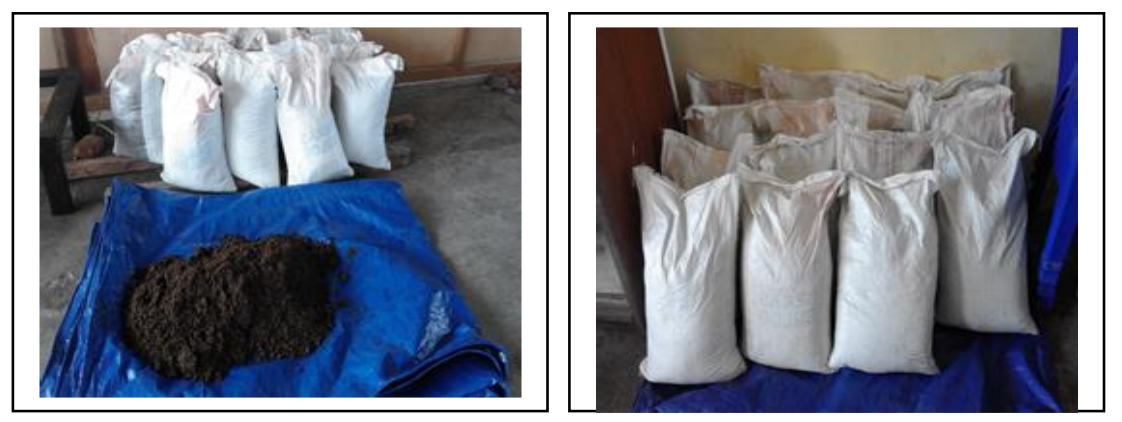

Gambar 4. Produk pupuk organik padat

\subsection{Pelatihan Manajemen Dan \\ Pengembangan Kelompok Simpan \\ Pinjam Untuk Usaha Perempuan (SPP)}

Pelatihan manajemen dan

pengembangan kelompok simpan pinjam untuk usaha perempuan (SPP) pada masyarakat di Desa Pakowa Bunta Kecamatan Nuhon Kabupaten Banggai dilaksanakan pada tanggal 3-4 Oktober 2016 di kantor Desa Pakowa Bunta Kecamatan Nuhon. Pelatihan manajemen dan pengembangan kelompok simpan pinjam untuk usaha perempuan (SPP) ini bertujuan untuk meningkatnya pengetahuan dan keterampilan masyarakat terutama kelompok ibu-ibu PKK dalam manajemen dan mengelola kelompok simpan pinjam untuk usaha perempuan (SPP). Kegiatan pelatihan ini terdiri dari pemaparan materi kegiatan dan kegiatan praktek pembukuan pengembangan kelompok PKK. Peserta kegiatan adalah ibu-ibu PKK Desa Pakowa Bunta Kecamatan Nuhon. Dalam pelaksanaan kegiatan ini berhasil $100 \%$ dan tidak ditemukan kendala yang berarti. Respon dari masyarakat Desa Pakowa Bunta Kecamatan Nuhon dalam mengikuti pelaksanaan kegiatan ini sangat mendukung. Kegiatan ini diharapkan agar masyarakat Desa Pakowa Bunta Kecamatan Nuhon terutama kelompok ibu-ibu PKK mengetahui manajemen dalam mengelola kelompok simpan pinjam untuk usaha perempuan (SPP) dan memiliki daftar program kerja kelompok usaha yang dilakukan oleh kelompok simpan pinjam untuk usaha perempuan (SPP). Dokumentasi kegiatan pelatihan manajemen dan pengembangan kelompok simpan pinjam untuk usaha perempuan (SPP) tertuang pada Gambar 5.
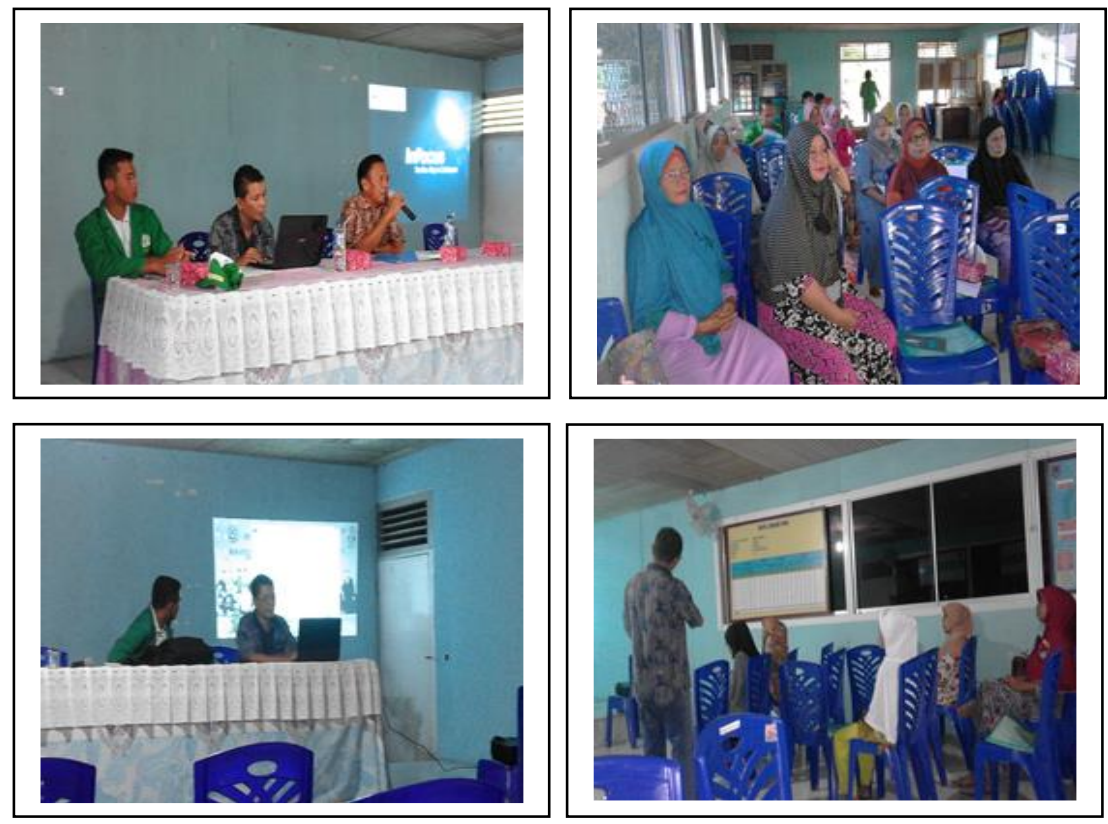

Gambar 5. Pelatihan manajemen dan pengembangan kelompok SPP 


\subsection{Sosialisasi Budidaya Ikan dan Pembuatan Pakan Ikan}

Kegiatan sosialisasi budidaya ikan pada masyarakat pembudidaya ikan di Desa Pakowa Bunta Kecamatan Nuhon Kabupaten Banggai dilaksanakan pada tanggal 9-10 Oktober 2016 di kantor Desa Pakowa Bunta Kecamatan Nuhon. Kegiatan sosialisasi budidaya ikan ini bertujuan untuk meningkatnya pengetahuan dan keterampilan kelompok masyarakat pembudidaya ikan yang sudah terbentuk dalam mengelola cara budidaya ikan yang baik dan benar. Sedangkan teknik pembuatan pakan ikan, pengeringan dan pengemasan pakan ikan dilaksanakan pada tanggal 11-18 Oktober 2016 di Gudang Koperasi Desa Pakowa Bunta Nuhon. Kegiatan pembuatan pakan ikan bertujuan agar masyarakat pembudidaya ikan nila dan ikan mas dapat membuat dan memformulasikan pakan ikan dengan bahan- bahan baku lokal yang tersedia di sekitar Desa Pakowa Bunta Kecamatan Nuhon.

Peserta kegiatan adalah kelompok pembudidaya ikan di Desa Pakowa Bunta Kecamatan Nuhon. Dalam pelaksanaan kegiatan ini berhasil $100 \%$ dan tidak ditemukan kendala yang berarti. Respon dari masyarakat Desa Pakowa Bunta Kecamatan Nuhon dalam mengikuti pelaksanaan kegiatan ini sangat mendukung. Kegiatan ini diharapkan agar masyarakat Desa Pakowa Bunta Kecamatan Nuhon terutama kelompok pembudidaya ikan dapat memanfaatkan secara optimal lahan kolam yang tersedia di desa untuk budidaya ikan dan dapat meningkatnya produksi ikan yang ada di Desa Pakowa Bunta Kecamatan Nuhon. Dokumentasi kegiatan sosialisasi budidaya ikan, proses pembuatan pakan ikan pada Gambar 6 serta produk pakan ikan tertuang pada Gambar 7.
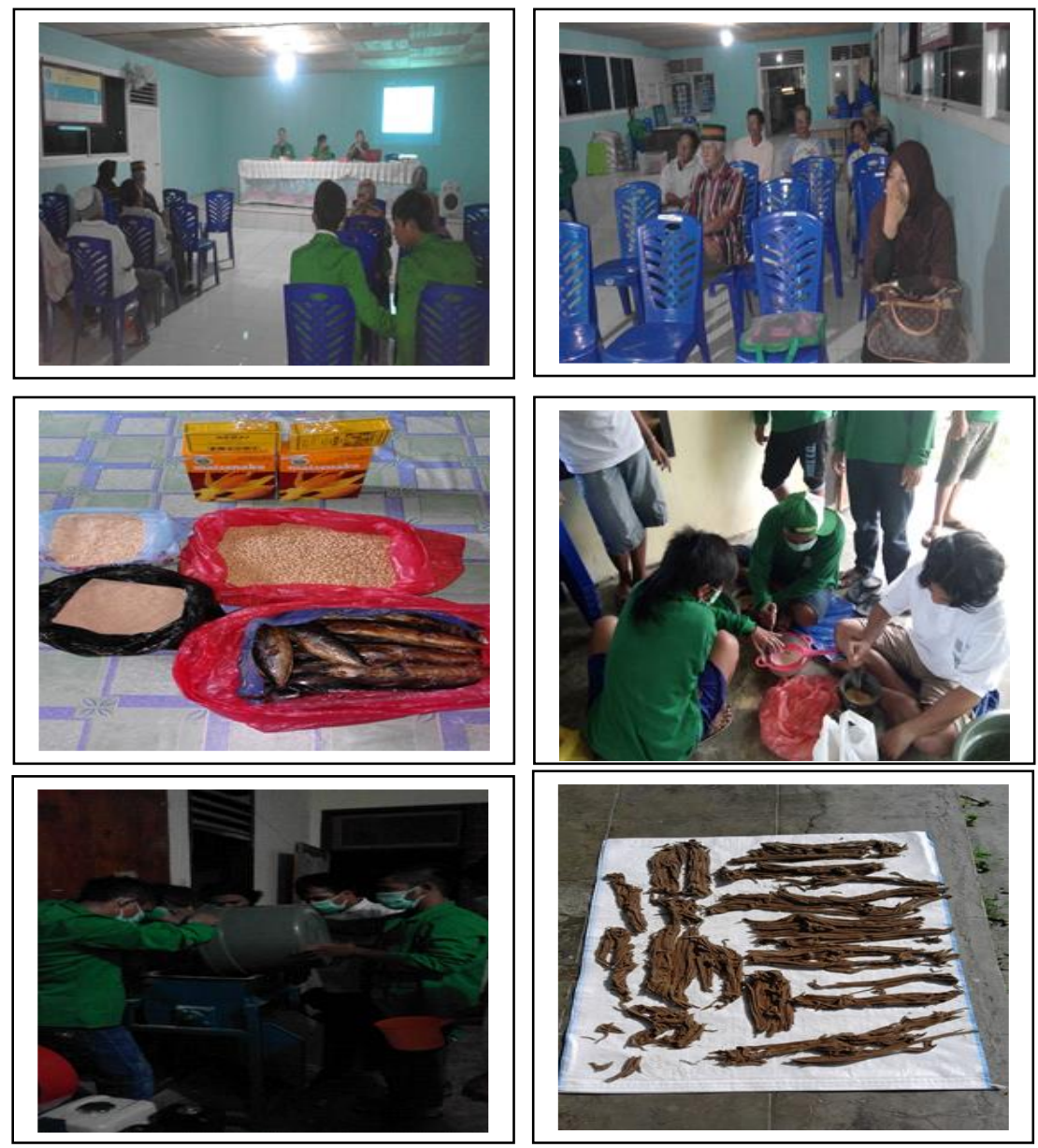

Gambar 6. Sosialisasi budidaya ikan dan proses pembuatan pakan ikan 

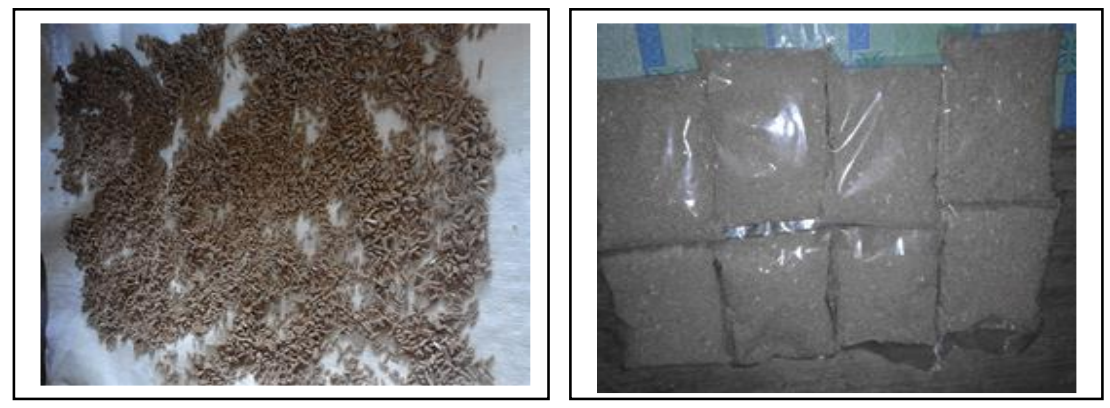

Gambar 7. Produk pakan ikan

\subsection{Pelatihan dan Pembuatan Kerajinan dari Tempurung Kelapa}

Pelatihan dan pembuatan kerajinan dari tempurung kelapa pada masyarakat di Desa Pakowa Bunta Kecamatan Nuhon Kabupaten Banggai dilaksanakan pada tanggal 18-27 Oktober 2016 di kantor Desa Pakowa Bunta Kecamatan Nuhon dan Gudang Koperasi Desa Pakowa Bunta Kecamatan Nuhon. Pelatihan dan pembuatan kerajinan dari tempurung kelapa ini bertujuan untuk meningkatnya pengetahuan dan keterampilan masyarakat terutama karang taruna dan kelompok ibu-ibu PKK dalam pembuatan kerajinan dari tempurung kelapa yang mempunyai nilai ekonomi lebih tinggi.

Peserta kegiatan adalah karang taruna dan ibu-ibu PKK Desa Pakowa Bunta
Kecamatan Nuhon. Dalam pelaksanaan kegiatan ini berhasil $100 \%$ dan tidak ditemukan kendala yang berarti. Respon dari masyarakat Desa Pakowa Bunta Kecamatan Nuhon dalam mengikuti pelaksanaan kegiatan ini sangat mendukung. Kegiatan ini diharapkan agar masyarakat Desa Pakowa Bunta Kecamatan Nuhon terutama karang taruna dan kelompok ibu-ibu PKK dapat memanfaatkan secara optimal sehingga bisa mempunyai usaha kerajinan dari tempurung kelapa yang dilakukannya mampu memproduksi dalam skala besar dan bisa diekspor. Dokumentasi kegiatan pelatihan, proses pembuatan dan produk kerajinan dari tempurung kelapa tertuang pada Gambar 8 dan Gambar 9.
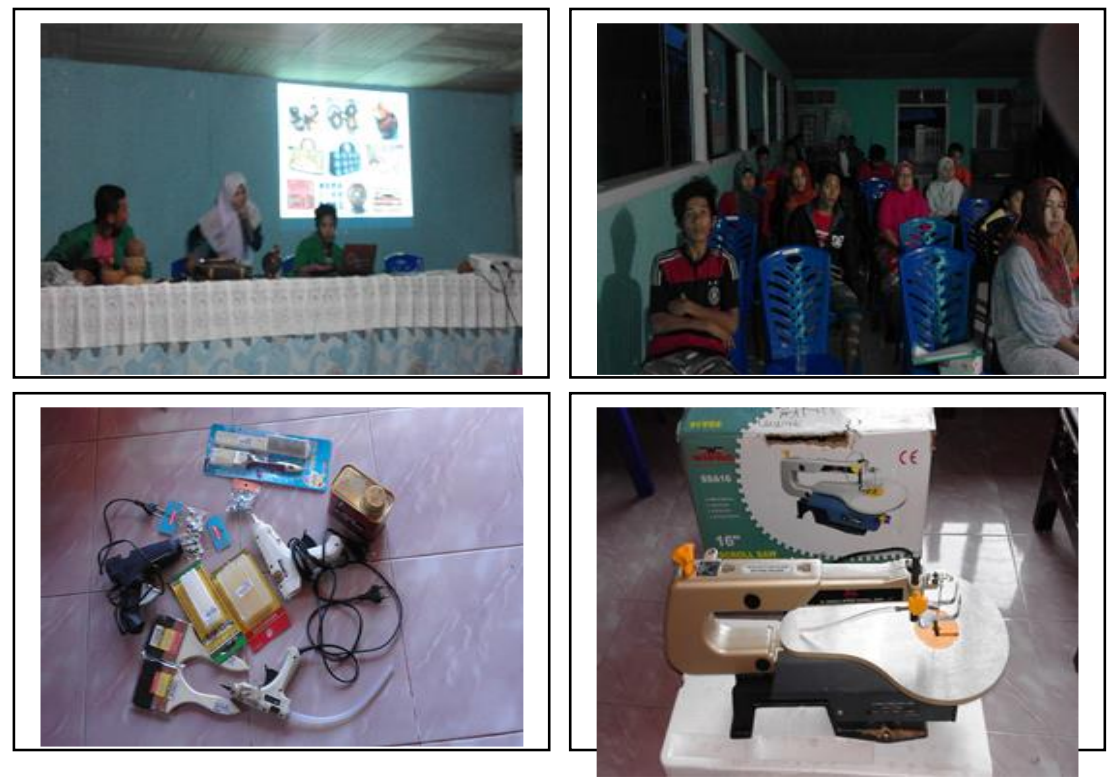

Gambar 8. Pelatihan dan peralatan untuk pembuatan kerajinan dari tempurung kelapa 

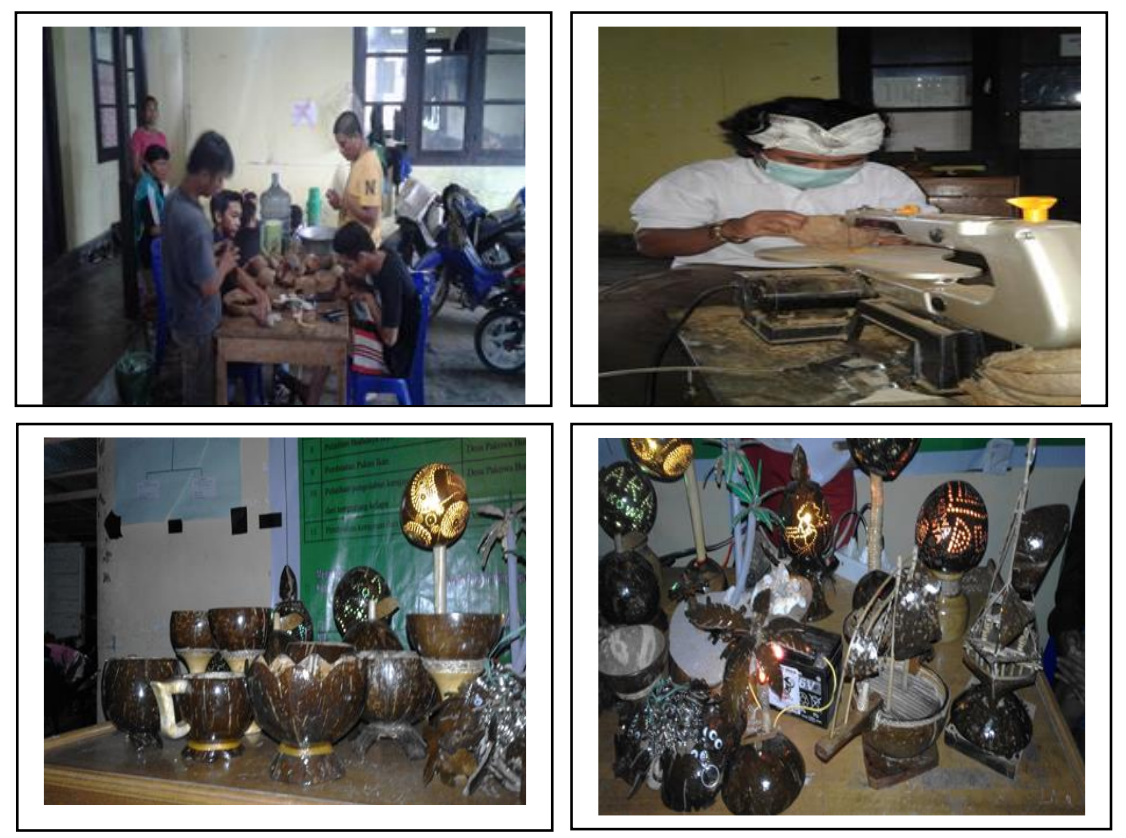

Gambar 9. Proses pembuatan dan produk kerajinan dari tempurung kelapa

\section{KESIMPULAN DAN SARAN}

Kesimpulan yang dapat diperoleh dari pelaksanaan program KKN-PPM Universitas Muhammadiyah Luwuk Tahun 2016 adalah:

1. Tingkat partisipasi yang tinggi dari mitra program KKN-PPM memberikan dampak positif bagi pelaksanaan program, terlihat dari sosialisasi dan pelatihan yang diberikan dapat berjalan dengan baik

2. Hasil kegiatan KKN-PPM diperoleh output kegiatan yaitu meningkatnya pengetahuan dan keterampilan masyarakat dalam : (1) mengolah dan membuat kelapa menjadi minyak goreng Bio Virgin, (2) memanfaatkan limbah pertanian menjadi pupuk organik padat, (3) manajemen dan mengelola kelompok simpan pinjam untuk usaha perempuan (SPP), (4) sosialisasi budidaya ikan dan membuat pakan ikan dan (5) membuat kerajinan dari tempurung kelapa yang mempunyai nilai ekonomi Saran lebih tinggi.

Tingginya motivasi masyarakat Desa Pakowa Bunta Kecamatan Nuhon dalam mengikuti kegiatan-kegiatan yang tertuang dalam program KKN-PPM Universitas Muhammadiyah Luwuk Tahun 2016 diharapkan mendapatkan perhatian khusus Pemerintah Kabupaten Banggai umumnya dan Pemerintah Desa Pakowa Bunta Kecamatan
Nuhon khususnya, sehingga menjadi keberlanjutan program dari kegiatan-kegiatan yang telah dilaksanakan serta peningkatan pengabdian kepada masyarakat dengan program pendampingan lainnya.

\section{DAFTAR PUSTAKA}

Anonymous. 2011. Rencana Pembangunan Jangka Menengah Desa Pakowa Bunta Tahun 2010-2015. Pemerintah Kabupaten Banggai Kecamatan Nuhon.

BPS. 2013. Kabupaten Banggai Dalam Angka. Badan Pusat Statistik Kabupaten Banggai.

DP2M DIKTI. 2013. Panduan Pelaksanaan Hibah Kuliah Kerja NyataPembelajaran Pemberdayaan Masyarakat (KKN-PPM). DP2M DIRJEN DIKTI. Kementrian Pendidikan dan Kebudayaan Republik Indonesia. Jakarta.

DRPM KEMENRISTEK DIKTI. 2016. Panduan Pelaksanaan Penelitian dan Pengabdian kepada Masyarakat di Perguruan Tinggi Edisi X. Direktorat Riset dan Pengabdian kepada Masyarakat, Direktorat Jenderal Penguatan Riset dan Pengembangan Kementerian Teknologi dan Pendidikan Tinggi. Jakarta. 
Setiaji AH. B. 2005. Menyingkap Keajaiban

Minyak Kelapa Virgin. Penerbit Pusat

Pengolahan Kelapa Terpadu.

Jogyakarta. 